\title{
PERBANDINGAN RBL DAN PBL TERHADAP HASIL BELAJAR MATEMATIKA PESERTA DIDIK DI MAN 12 JAKARTA
}

\author{
Aswin Saputra \\ Dosen Program Studi Teknik Informatika, Fakultas Teknik, Matematika, dan IPA \\ Universitas Indraprasta PGRI
}

\begin{abstract}
This study aims to determine differences in mathematics learning outcomes of students who use the RBL approach to PBL approach in MAN 12 Jakarta. The population in this study were 180 students of class $X$ of MAN 12 Jakarta. Samples are 72 students, is determined by purposive sampling. Descriptive analysis revealed, that the mathematics learning outcomes of students who use the RBL approach gives the average (mean $=16.333)$ and mathematics learning outcomes of students who use the PBL approach gives the average (mean $=14.444)$. The results of correlation analysis showed mathematics learning outcomes of students who use the RBL approach provides a large contribution of $16 \%\left(r_{\text {hitung }}=0.510 ; t=2.994\right)$ than the outcome of learning mathematics learners using PBL approach. The results of the t test revealed a significant difference between the results of learning mathematics learners who use the RBL approach to mathematics learning outcomes of students who use the PBL approach. Thus, we can conclude that there are significant differences in mathematics learning outcomes of students who use the RBL approach rather than the result of learning mathematics learners using Problem Based Learning approach in MAN 12 Jakarta.
\end{abstract}

Keyword: RBL, PBL, mathematics learning outcomes of students

\section{PENDAHULUAN}

Perkembangan ilmu pengetahuan dan teknologi telah membawa perubahan hampir disemua aspek kehidupan yang membawa manusia kedalam era persaingan Global yang semakin ketat. Salah satu dampak dari perubahan keadaan tersebut terlihat pada upaya mempersiapkan sumber daya manusia Indonesia yang berkualitas. Oleh karena itu, peningkatan kualitas sumber daya manusia harus dilakukan secara terencana, terarah, intensif, efektif, dan efisien dalam proses pembangunan.

Pembangunan memegang peran yang sangat penting dalam proses peningkatan kualitas sumber daya manusia (SDM). Dunia pendidikan harus mampu meyakinkan bahwa SDM yang dihasilkannya akan mempunyai kompetensi yang mampu bersaing dalam era Global. Oleh karena itu, program-program pendidikan yang ditawarkan harus mampu memberi bukti keterbentukkan kemampuan/kompetensi yang dianggap relevan dengan era Global. Mengingat peranannya yang sangat penting tersebut, maka bidang pendidikan perlu memiliki suatu sistem pendidikan nasional yang digunakan sebagai pedoman serta dapat digunakan untuk mengantisipasi semua permasalahan pendidikan dan menjawab tantangan masa depan. Salah satu permasalahan pendidikan pada setiap jenjang, jalur, dan jenis pendidikan, khususnya pendidikan dasar dan menengah. Untuk indikator rendahnya mutu pendidikan dapat dilihat dari tingkat hasil belajar peserta didik.

Berbagai usaha telah dilakukan untuk meningkatkan kualitas pendidikan nasional dan sekolah sebagai salah satu lembaga pendidikan formal terus berupaya menyelenggarakan kegiatan pendidikan yang lebih berkualitas antara lain melalui pengembangan dan perbaikan kurikulum, perbaikan sarana dan prasarana pendidikan, pengembangan, dan pengadaan materi ajar serta pelatihan tenaga kependidikan lainnya. Upaya-upaya tersebut dilakukan agar ada kesesuaian antara pendidikan dengan perkembangan ilmu pengetahuan dan teknologi, perkembangan masyarakat serta 
kebutuhan pembangunan. Kegiatan pendidikan yang dilakukan di sekolah merupakan suatu proses yang rumit.

Banyak faktor yang saling memengaruhi dan saling menunjang dalam kegiatan ini diantaranya yaitu: pendidik, peserta didik, materi pengajaran, dan pendekatan pembelajaran. Ketepatan dalam menggunakan pendekatan pembelajaran yang dilakukan oleh pendidik akan dapat meningkatkan proses pembelajaran dan hasil belajar peserta didik. Peserta didik akan mudah menerima materi yang diberikan oleh pendidik apabila pendekatan pembelajaran yang digunakan tepat dan sesuai dengan tujuan pengajaran. Pendekatan pembelajaran yang baik adalah pendekatan yang sesuai dengan materi yang akan disampaikan, kondisi peserta didik, sarana yang tersedia serta tujuan pengajarannya. Suatu pendekatan pembelajaran memiliki spesifikasi tersendiri, artinya suatu pendekatan yang cocok untuk suatu materi pelajaran tertentu belum cocok jika diterapkan pada materi yang lainnya.

Salah satu tugas utama pendidik adalah menjadikan pembelajaran itu bermakna yaitu: mempersiapkan materi yang diajarkan secara terprogram, memilih, dan menentukan pendekatan pembelajaran yang disesuaikan dengan materi yang diajarkan dan mengadakan evaluasi hasil belajar. Pembelajaran matematika di sekolah perlu ditekankan agar hasil belajar yang diperoleh relevan dengan kehidupan sehari-hari dan dapat diaplikasikan sehingga sesuai dengan kebutuhan. Pada umumnya pembelajaran matematika di sekolah masih terpusat pada pendidik sehingga posisinya sangat dominan. Akibatnya kegiatan belajar mengajar lebih menekankan pada pengajaran dari pada pembelajaran. Paradigma bahwa mengajar hanya merupakan transfer pengetahuan dari pendidik kepada peserta didik sehingga pembelajan matematika hanya dengan menghafal dan mengingat rumus.

Paradigma tersebut harus diubah agar pembelajaran berpusat pada peserta didik, pendidik perlu memilih suatu pendekatan yang memerlukan keterlibatan peserta didik secara aktif selama proses belajar mengajar sehingga tujuan pembelajaran tercapai.

Ada beberapa pendekatan yuang disarankan untuk membangun keterampilan berpikir tingkat tinggi peserta didik, yaitu:

a. Resource Based Learning (RBL) memiliki karakteristik dimana peserta didik diberikan berbagai ragam dan jenis bahan belajar baik cetak (buku, modul, LKS, dll) maupun noncetak (bahan belajar online, dll) atau sumber belajar lain (orang, alat, dll) yang relevan untuk mencapai suatu tujuan pembelajaran yang ingin dicapai. Kemudian peserta didik diberikan tugas untuk melakukan aktifitas belajar tertentu dimana semua sumber belajar yang mereka butuhkan telah disediakan. Sebagai contoh, tujuan pembelajaran yang ingin dicapai adalah peserta didik dapat membandingkan beberapa teori penciptaan alam semesta. Agar dapat mencapai tujuan pembelajaran tersebut, pendidik telah mengidentifikasikan dan menyiapkan berbagai bentuk dan jenis sumber belajar yang berisi informasi tentang teori penciptaan alam semesta berupa buku, CD interaktif, alamat situs diinternet dan mungkin seorang narasumber ahli astronomi yang diundang khusus kedalam kelas. Kemudian, peserta didik ditugaskan untuk mencari minimal dua teori tentang penciptaan alam semesta secara individu atau kelompok baik dari buku, maupun internet sesuai dengan kemampuannya. Peserta didik juga diminta untuk menganalisis perbedaan dari berbagai segi tentang teori-teori tersebut dan membuat laporannya, kemudian dikirim kepada pendidik dan temanteman lainnya melalui e-mail.

b. Problem Based Learning (PBL) memberi kemungkinan solusi pemecahan masalahnya akan berbeda. Misalnya, dua peserta didik diberikan satu permasalahan dengan 
pendekatan PBL. Maka solusi yang ditawarkan oleh peserta didik yang satu dengan peserta didik yang lain mungkin berbeda. Pendekatan PBL adalah penggunaan proyek sebagai metode pembelajaran. Para peserta didik bekerja secara nyata, seolah-olah ada di dunia nyata yang dapat menghasilkan produk secara realitis. Dari pengalaman terdapat dua dimensi untuk menggolongkan alternatif PBL: 1) Penyelesaian tugas dan pembelajaran pengetahuan yang pokok, 2) Manajemen proyek dan pembelajaran skill secara umum. Aktifitasnya para pendidik dan para peserta didik bertukar, tergantung pada derajat tingkat kendali yang diberikan kepada para peserta didik dalam dua dimensi.

\section{TINJAUAN PUSTAKA \\ Belajar}

Belajar adalah peubahan yang relative permanen dalam perilaku atau potensi sebagai hasil dari pengalaman atau latihan yang diperkuat. Perubahan akibat belajar dapat terjadi dalam berbagai bentuk perilaku, dari ranah kognitif, afektif, dan psikomotor. Tidak terbatas hanya penambahan pengetahuan saja. Sifat perubahan relative permanen, tidak akan kembali kepada keadaan semula. Tidak bias diterapkan pada perubahan akibat situasi sesaat, seperti perubahan akibat kelelahan, sakit, mabuk, dan sebagainya.

Menurut Syaiful Sagala (2004:12) bahwa, belajar adalah kegiatan individu memperoleh pengetahuan, perilaku, dan keterampilan dengan cara mengolah bahan belajar. Belajar merupakan suatu proses perubahan tingkah laku sebagai hasil dari interaksi dengan lingkungannya dalam memenuhi kebutuhan hidupnya. Perubahan tersebut akan nyata dalam berbagai bentuk, seperti perubahan pengetahuan, pemahaman sikap, dan tingkah laku kebiasaan serta aspek-aspek yang ada pada individu yang belajar.

\section{Matematika}

Matematika timbul karena pikiran-pikiran manusia yang berhubungan dengan ide dan penalaran. Ide-ide yang dihasilkan oleh pikiran-pikiran manusia itu merupakan sistem-sistem yang bersifat untuk mengambarkan konsep-konsep abstrak, dimana masing-masing sistem bersifat deduktif sehingga berlaku umum dalam menyelesaikan masalah.

Matematika merupakan ilmu universal yang mendasari perkembangan teknologi modern, mempunyai peran penting dalam berbagai disiplin ilmu dan mengembangkan daya pikir manusia. Perkembangan pesat dibidang teknologi informasi dan teknologi dewasa ini dilandasi oleh perkembangan matematika dibidang teori bilangan, aljabar, analisis, teori peluang, dan matematika diskret. Demi menguasai dan menciptakan teknologi diamasa depan diperlukan penguasaan Matematika yang kuat sejak dini. Manurut Andi (1982:12) bahwa istilah matematika berasal dari kata Yunani mathein atau manthenein yang artinya mempelajari.

Matematika merupakan bidang studi yang dipelajari oleh semua peserta didik mulai dari sekolah dasar sampai perguruan tinggi. Pelajaran matematika diberikan di sekolah bukan hanya dalam rangka pendidikan tertentu yang menjadikan sebagai ilmu penunjangnya, tetapi juga dalam rangka pembentukan sikap dan kepribadian agar dapat berpikir logis, analisis, rasional, sistematis, kritis, dan kreatif serta kemampuan kerja sama. Menurut Lydia Polonsky (2005:2) bahwa, Matematika adalah bagian dari rutinitas sehari-hari-mengukur dan mencatat suhu, mencatat banyaknya hari anak-anak berada disekkolah, menandai tanggal dikalender, berhitung, menaksir, dan mengajukan pertanyaan seperti "Apakah ada pola diruangan ini?" 
Pelajaran matematika sebenarnya hamper disemua pokok bahasannya hanya membahas tentang bilangan, hubungan-hubungan antar bilangan, dan prosedur operasional yang digunakan dalam penyelesaian masalah tentang bilangan. Bilangan yang dimaksud disini masih sangat umum, karena matematika suatu bidang ilmu yang banyak menggunakan bilangan. Matematika disebut raja ilmu dalam komunikasi ilmiah karena hampir disemua disiplin ilmu pengetahuan menggunakan matematika juga disebut pelayan ilmu dalam komunikasi ilmiah karena ilmu pengetahuan lain membutuhkan (bantuan) matematika.

Jadi, matematika dalam hal ini adalah alat hitung yang berlandaskan pada rasional, sistematis, dan kritis yang dibutuhkan oleh semua ilmu pengetahuan. Tanpa bantuan matematika semua tidak akan mendapatkan kemajuan yang berarti.

\section{Hasil belajar}

Berdasarkan teori Taksonomi Bloom, hasil belajar dalam rangka studi dicapai melalui tiga kategori ranah yaitu:

a. Kognitif, berkenaan dengan hasil belajar intelektual yang terdiri dari pengetahuan, pemahaman, penerapan, analisis, sintesis, dan penilaian

b. Afektif, berkenaan dengan sikap dan nilai. Ranah afektif meliputi menerima, menjawab, menilai, organisasi, dan karakteristik dengan suatu nilai atau kompleks nilai.

c. Psikomotor, meliputi keterampilan motorik, manipulasi benda, koordinasi neuromuscular (menghubungkan, mengamati).

Menurut Nana Sudjana (2004:22) bahwa, hasil belajar adalah kemampuankemampuan yang dimiliki peserta didik setelah menerima pengalaman belajarnya. Kemampuan merupakan faktor penting yang berpengaruh terhadap hasil belajar peserta didik, kemampuan tersebut berasal dari dalam diri peserta didik.

Menurut Nasution (1992:39) bahwa, hasil belajar adalah suatu perubahan yang terjadi pada individu yang belajar bukan saja perubahan mengenai pengetahuan tetapi juga dalam bentuk kecakapan, kebiasaan sikap, pengertian, penguasaan, dan penghargaan dalam pribadi individu yang belajar.

Penguasaan hasil belajar seseorang dapat dilihat dari perilaku, baik perilaku dalam bentuk penguasaan materi, pengetahuan, keterampilan berpikir, maupun keterampilan motorik. Agar mempeoleh hasil belajar yang optimal, peserta didik harus berusaha belajar dengan tekun, untuk mengetahui keberhasilan kegiatan belajar mengajar, maka dilakukan penilaian terhadap hasil belajar peserta didik. Hasil belajar yang didapat dijadikan sebagai tolak ukur bagi peserta didik untuk dapat belajar lebih giat agar memdapatkan hasil yang maksimal. Penilaian tersebut juga dapat dijadikan acuan bagi pendidik untuk meningkatkan pengajarannya.

Jadi, hasil belajar yang dimaksud dalam hal ini adalah realisasi dari kecakapankecakapan potensial yang dimiliki berupa kemampuan-kemampuan yang dimiliki peserta didik setelah menerima pelajaran dari pendidik.

\section{Pembelajaran Resouce Based Learning (RBL)}

Pembelajaran ini mencakup berbagai cara dan sarana dimana peserta didik dapat belajar dengan cara apapun mulai dari mendapatkan bantuan dari guru sampai belajar secara mandiri. 
Menurut Nasution (2010:18) bahwa, Resouce Based Learning adalah segala bentuk belajar yang langsung menghadapkan peserta didik dengan sesuatu atau sejumlah individu atau kelompok dengan segala kegiatan belajar yang berkaitan dengan itu, bukan dengan cara konvensional dinama pendidik menyampaikan beban pelajaran kepada peserta didik.

RBL merupakan pembelajaran berbasis sumber yaitu suatu sistem belajar yang berorientasi pada siswa yang menggunakan aneka sumber dalam proses pembelajarannya. Penerapannya bebas secara luas juga dapat dikaitkan dengan jenis sistem pendidikan terbukan, jarak, jauh, belajar fleksibel yang menggunakan aneka sumber.

Menurut Syaiful Sagala (2004:65) bahwa, Resource Based Learning ialah sagala bentuk belajar yang langsung menghadapkan peserta didik dengan suatu atau sejumlah sumber belajar secara individual atau kelompok dengan segala kegiatan belajar yang bertalian dengan itu, jadi bukan dengan cara yang konvensional dimana pendidik menyampaikan bahan pelajaran pada peserta didik, tetapi setiap komponen yang dapat membrikan informasi seperti perpustakaa, laboratorium, kebun, dan semacamnya juga merupakan sumber belajar.

Jadi, RBL yang dimaksud dalam hal ini adalah pendekatan pembelajaran yang berdasarkan pada sumber-sumber belajar yang bebas namun disesuaikan dengan kondisi keadaannya.

\section{Pembelajaran Problem Based Learning (PBL)}

Pada prinsipnya, program pembelajaran tidak hanya memahami dan menguasai apa dan bagaimana sesuatu terjadi, tetapi memberikan pemahaman mengenai mengapa hal itu terjadi. Berpijak pada permasalahan tersebut, maka pembelajaran berbasis masalah sangat penting untuk diterapkan. Pada dasarnya tujuan akhir pembelajaran adalah menghasilkan siswa yang memiliki pengetahuan dan keterampilan dalam memecahkan masalah dalam diri sendiri maupun masalah dalam kehidupan bermasyarakat. Guna menghasilkan siswa yang memiliki kompetensi yang handal dalam pemecahan masalah maka diperlukan serangkaian strategi pembelajaran pemecahan masalah yang dapat diterapkan dalam pembelajaran.

Menurut Taufiq (2010:12) bahwa, Pembelajaran dimulai dengan pemberian masalah, biasanya masalah memiliki konteks dengan dunia nyata, pemelajar secara berkelompok aktif merumuskan masalah dan mengidentifikasi kesenjangan pengetahuan mereka, mempelajari, dan mencari sendiri materi yang terkait dengan masalah dan melaporkan solusi dari masalah.

PBL merupakan pendekatan pembelajaran yang dimulai dengan menyelesaikan suatu masalah, tetapi untuk menyelesaikan masalah itu peserta didik memerlukan pengetahuan baru untuk dapat menyelesaikannya.

Jadi, pendekatan PBL dalam hal ini adalah sebuah pendekatan yang berdasarkan pada permasalahan kehidupan sehari-hari dengan dibuatnya kelompok-kelompok yang dipandu oleh pendidik dengan menggunakan permasalahan sebagai pemicunya.

Penelitian ini bertujuan untuk mengetahui, ada atau tidaknya perbedaan hasil belajar matematika peserta didik yang menggunakan RBL dengan siswa yang menggunakan PBL. 


\section{METODOLOGI PENELITIAN}

Penelitian ini menggunakan metode eksperimen, diamana penulis turun langsung mengajar pada kelas eksperimen yang menggunakan pendekatan RBL dan di kelas kontrol yang menggunakan PBL.

Penelitian ini dilakukan di MAN 12 Kecamatan Cengkareng, Jakarta Barat. Penelitian dilaksanakan selama April 2011. Penelitian ini merupakan penelitian kuantitatif dengan analisis data menggunakan uji t.

Desain penelitian ini menggunakan Quasi Eksperimental Design, dimana desain ini memiliki kelompok kontrol, tetapi tidak dapat berfungsi sepenuhnya untuk mengontrol variabel-variabel luar yang memengaruhi pelaksanaan eksperimen. Adapun desain penelitiannya sebagai berikut.

Tabel 1. Desain Penelitian

\begin{tabular}{llll}
$\mathbf{E}$ & $O_{1}$ & $X$ & $O_{2}$ \\
\hline $\mathbf{K}$ & $O_{1}$ & & $O_{2}$ \\
\hline
\end{tabular}

Keterangan:

E : Kelompok Eksperimen

$\mathrm{K}$ : Kelompok Kontrol

$\mathrm{X}$ : Perlakuan

$\mathrm{O}_{1}$ : Pemberian pretest pada kelompok eksperimen

$\mathrm{O}_{2}$ : Pemberian postest pada kelompok eksperimen

$\mathrm{O}_{3}$ : Pemberian pretest pada kelompok kontrol

$\mathrm{O}_{4}$ : Pemberian postest pada kelompok kontrol

Desain ini hampir sama dengan pretest-postest control group design, hanya pada desain ini kelompok eksperimen maupun kelompok kontrol tidak dipilih secara acak. Pengambilan sampel dilakukan dengan teknik sampling purposive, dimana teknik penentuan sampel dengan pertimbangan tertentu, misalnya keterbatasan waktu, tenaga, dan dana sehingga tidak dapat mengambil sampel yang besar dan jauh. Sampel yang menjadi target penelitian ini adalah kelas X IPS 1 berjumlah 36 peserta didik (kelompok eksperimen), dan kelas X IPS 2 berjumlah 36 peserta didik (kelompok kontrol).

\section{HASIL DAN PEMBAHASAN}

\section{Hasil Penelitian}

Secara deskriptif, data penelitian ini dapat dinyatakan dalam tabel 2.

Tabel 2. Statistika Deskriptif Pendekatan RBL, Pendekatan PBL, dan Hasil Belajar Matematika Statistik deskriptif Hasil Belajar Matematika yang menggunakan Pendekatan

Hasil Belajar Matematika yang Resource Based Learning menggunakan Pendekatan Problem Based Learning

\begin{tabular}{lcc}
\hline Maksimum & 22 & 20 \\
Minimum & 11 & 9 \\
Rerata & 16,333 & 14,444 \\
\hline Median & 17 & 15 \\
Modus & 18 & 15 \\
\hline Simpangan baku & 2,756 & 2,568 \\
\hline
\end{tabular}


Dari tabel 2, terlihat bahwa hasil belajar matematika yang menggunakan pendekatan RBL tergolong baik, hal ini terlihat dari nilai rerata, median, dan modus yang nilainya mendekati skor maksimum yang mungkin dicapai untuk variabel pendekatan RBL. Kemudian, hasil belajar matematika yang menggunakan pendekatan PBL tergolong cukup baik, terlihat nilai rerata, median, dan modus yang nilainya mendekati skor maksimum yang mungkin dicapai untuk variabel pendekatan PBL.

Sebelum dilakukan pengujian hipotesis, terlebih dahulu dilakukan pengujian persyaratan analisis data yang terdiri dari uji normalitas dan uji homogenitas. Pengujian normalitas dilakukan untuk mengetahui distribusi data setiap variabel yang diteliti apakah berdistribusi normal atau tidak. Pengujian normalitas menggunakan uji Lilliefors karena data dalam bentuk tunggal dan dihitung dengan tabel penolong dengan kriteria pengujian jika $L_{0}<L_{\text {tabel }}$ data berdistribusi normal, dan $L_{0} \geq L_{\text {tabel }}$ data berdistribusi tidak normal. Untuk taraf nyata $\alpha=5 \%$, dalam perhitungan diperoleh $L_{0}=0,079$ dengan $n=36$, karena $L_{0}<L_{\text {tabel }}$ yaitu $0,079<0,147$, maka $H_{0}$ diterima. Berarti sampel yang digunakan berasal dari populasi yang berdistribusi normal.

Tabel 3. Ringkasan Hasil Uji Normalitas

\begin{tabular}{lccc}
\multicolumn{1}{c}{ Variabel } & Nilai $L_{0}$ & Nilai $L_{\text {tabel }}$ & Keterangan \\
\hline $\begin{array}{l}\text { Hasil belajar matematika yang } \\
\text { menggunakan Pendekatan RBL }\end{array}$ & 0,079 & 0,147 & $\begin{array}{c}\text { Berdistribusi } \\
\text { Normal }\end{array}$ \\
$\begin{array}{l}\text { Hasil belajar matematika yang } \\
\text { menggunakan Pendekatan PBL }\end{array}$ & 0,108 & 0,147 & $\begin{array}{c}\text { Berdistribusi } \\
\text { Normal }\end{array}$ \\
\hline
\end{tabular}

Pengujian homogenitas variansi yang digunakan adalah uji Bartlet dimaksudkan untuk memperlihatkan bahwa variansi sampel-sampel yang akan dibandingkan tidak berbeda secara signifikan. Kriteria pengujian dengan $d k=n-1=35$, taraf nyata $\alpha=5 \%, \chi_{\text {hit }}^{2}<\chi_{\text {tabel }}^{2}$ maka varians-varians adalah homogen.

Tabel 4. Ringkasan Hasil Uji Homogenitas

\begin{tabular}{ccc} 
Nilai $\chi_{\text {hit }}^{\mathbf{2}}$ & Nilai $\chi_{\text {tabel }}^{2}$ & Keterangan \\
\hline $\mathbf{0 , 2 3 9 2}$ & 3,841 & Homogen \\
\hline
\end{tabular}

Dari tabel 4, terlihat bahwa nilai $\chi_{\text {hit }}^{2}<\chi_{\text {tabel }}^{2}$ sehingga dapat disimpulkan varians-varians adalah homogen.

Setelah melakukan uji persyaratan analisis data, langkah selanjutnya dilakukan perhitungan pengujian hipotesis yaitu dengan uji t. Untuk menguji hipotesis digunakan derajat kebebasan pada taraf nyata $\alpha=5 \%$, terima $H_{0}$ jika $-t_{1-\frac{\alpha}{2}}<t_{1-\frac{\alpha}{2}}$ dimana $t_{1-\frac{\alpha}{2}}$ didapat dari daftar distribusi t dengan $d k=\left(n_{1}+n_{1}-2\right)$ dan peluang $\left(1-\frac{\alpha}{2}\right)$, dan sebaliknya tolak $H_{0}$ jika mempunyai nilai $t$ lain.

\section{Pembahasan}

Penelitian ini telah menemukan bahwa terdapat perbedaan hasil belajar matematika peserta didik yang diajar menggunakan pendekatan RBL dengan pendekatan PBL. Hasil ini sekaligus membuktikan bahwa perbedaan rerata hasil belajar matematika peserta didik bukan suatu kebetulan, tetapi karena perbedaan perlakuan yang diberikan 
kepada setiap kelas, sehingga dapat disimpulkan bahwa pembelajaran menggunakan pendekatan RBL dapat berpengaruh positif terhadap hasil belajar matematika peserta didik, serta efektif dan efisien proses belajar mengajar matematika dapat ditingkatkan dengan pendekatan PBL.

\section{SIMPULAN DAN SARAN \\ Simpulan}

Berdasarkan hasil penelitian, maka dapat ditarik simpulan, yaitu:

1. Perbedaan nilai rerata hasil belajar matematika kelas yang menggunakan pendekatan RBL dan kelas yang menggunakan pendekatan PBL pada subbab ukuran tendensi pusat adalah 16,333 dengan 14,444.

2. Perbandingan hasil uji normalitas hasil belajar matematika peserta didik pada bahasan statistika yang menggunakan pendekatan RBL di kelas eksperimen adalah $L_{0}<L_{\text {tabel }}$ atau $0,104<0,148$. Hal ini menunjukkan bahwa kelas eksperimen dan kelas kontrol berdistribusi normal.

3. Perhitungan uji homogenitas kedua kelas tersebut adalah $\chi_{\text {hitung }}^{2}<\chi_{\text {tabel }}^{2}$ atau 0,2392 $<3,841$, maka varians-varians adalah homogen.

4. Perhitungan pengujian hipotesis dua pihak diperoleh $t_{\text {hitung }}>t_{\text {tabel }}$ atau 2,994 $>$ 1,996, maka $H_{1}$ diterima sendangkan $H_{0}$ ditolak. Sehingga dinyatakan terdapat perbedaan hasil belajar matematika peserta didik yang menggunakan pendekatan RBL dengan pendekatan PBL, karena bias dilihat rerata dan skor hasil belajar kedua pendekatan tersebut.

\section{Saran} berikut:

Berdasarkan simpulan di atas, maka peneliti mengajukan beberapa saran sebagai

1. Diharapkan kepada pendidik matematika, untuk lebih melibatkan peserta didik dalam kegiatan belajar mengajar, agar mendapatkan pengalaman belajar yang maksimal seperti pada pembelajaran PBL dan Cooperative Learning yang membuat peserta didik akan lebih termotivasi untuk belajar aktif, kreatif, dan inovatif dalam menyelesaikan masalah.

2. Diharapkan pula kepada pendidik matematika untuk mempersiapkan dengan baik dan sistematis scenario pembelajaran yang akan ditetapkan dalam kegiatan belajar mengajar, agar tujuan pembelajaran tercapai.

3. Pendekatan RBL dapat diterapkan oleh pendidik sebagai alternatif pengajaran yang selama ini menggunakan pendekatan klasik. Diharapkan kepada pendidik matematika mengingkatkan kemampuan dan keterampilan dalam mengkondisikan kelas, sehingga tercipta suasana kelas kondusif, sehingga kegiatan belajar mengajar menjadi dinamis.

4. Hasil penelitian ini tentu bukan hasil akhir dan masih sangat sederhana, dengan segala keterbatasan yang ada dalam penelitian ini, dapat dijadikan referensi untuk penelitian lebih lanjut, dengan memperhatikan segala kemungkinan adanya variabelvariabel yang turut memengaruhi pembelajaran dengan pendekatan RBL. 


\section{DAFTAR PUSTAKA}

Arikunto, Suharsimi. 2009. Dasar-Dasar Evaluasi Pendidikan (Edisi Revisi). Yogyakarta: Bumi Aksara. 2009. Prosedur Penelitian Suatu Pendekatan Praktik. Yogyakarta: Rineka Cipta.

Astra, I. (2007) Pengembangan bahan ajar berorientasi pada Resource Based Learning untuk calon guru SMA. TEKNODIK, h. 66-63

A.M, Sardiman. 2010. Interaksi \& Motivasi Belajar Mengajar. Jakarta: PT Raja Grafindo Persada.

Arsyad, Azhar. 2002. Media Pembelajaran. Jakarta: PT RajaGrafindo Persada.

B. Uno, Hamzah \& Kuadrat, Masri. 2009. Mengelola Kecerdasan Dalam Pembelajaran: Sebuah Konsep Pembelajaran Berbasis Kecerdasan. Gorontalo: PT Bumi Aksara.

Riduwan. 2004. Belajar Mudah Penelitian utuk Guru-Karyawan dan Peneliti Pemula. Bandung: Alfabeta.

Rusman. 2010. Model-Model Pembelajaran: Mengembangkan Profesionalisme guru. Bandung: PT RajaGrafindo Persada.

Rusmono. 2012. Strategi Pembelajaran dengan Problem Based Learning itu perlu. Jakarta: Ghalia Indonesia.

Sudijono, Anas. 2013. Pengantar Evaluasi Pendidikan. Jakarta: PT RajaGrafindo Persada.

Stone, Randi. (Suci Romadhona, Penerjemah). 2009. Cara-cara Terbaik Mengajarkan Matematika. Jakarta: PT INDEKS.

Zulaiha, Rahma. 2008. Analisis soal secara manual. Jakarta: Departemen Pendidikan Nasional, Badan Penelitian dan Pengembangan, Pusat Penilaian Pendidikan. 